\title{
Nutritional content of few foods diet in atopic dermatitis
}

\author{
D C Mabin, A E Sykes, T J David
}

\begin{abstract}
The nutritional content of a few foods diet, supplemented with a casein hydrolysate formula $(n=24)$ or a whey hydrolysate formula $(n=21)$, was studied in 45 children with atopic dermatitis. The six day weighed food inventory record method was used to estimate the mean daily intake of energy, protein, calcium, iron, zinc, folate, and vitamin $C$ on normal diet and on the few foods diet. The diet was associated with a significant reduction in protein and calcium intake in both groups, and in energy intake in the casein hydrolysate group. The median daily volume of hydrolysate milk taken was $10 \cdot 5$ $\mathrm{ml} /$ day (range $0-840 \mathrm{ml} /$ day) for the casein hydrolysate group and $267 \mathrm{ml} /$ day (range 0-1300 ml/day) for the whey hydrolysate group. Whey hydrolysate appears to be more palatable than casein hydrolysate, which is a potential advantage in the maintenance of an adequate intake in children on a few foods diet.

(Arch Dis Child 1995; 73: 208-210)
\end{abstract}

Keywords: few foods diet, nutritional content, atopic dermatitis.

In a few foods diet, all but a small number of foods are excluded for a defined period, up to six weeks. ${ }^{1-5}$ However there has been no study of the nutritional adequacy of such extreme forms of dietary manipulation. The aim of this study was to examine the change in intake of important selected nutrients in children placed on a few foods diet, supplemented in a double blind manner with either a casein hydrolysate formula, Nutramigen (Mead Johnson), or a whey hydrolysate formula, Nutrilon Pepti Plus (Nutricia Cow and Gate).

\section{Methods}

Patients were studied as part of a controlled clinical trial to examine the effect of a few foods diet supplemented with a hydrolysate formula milk in atopic dermatitis. ${ }^{1}$ Dietetic assessment was carried out using the six day weighed food record technique ${ }^{6}$ on two occasions, once while the child was on a normal diet, and again when child was established on the few foods diet. Parents weighed to the nearest gram all food and leftovers using electronic scales. Parents also measured the volume of all drink taken for six consecutive days, including four weekdays and two weekend days. The change in milk intake was calculated by expressing the mean daily intake of hydrolysate formula during the few foods diet as a percentage of the mean daily intake of milk on the child's normal diet.

Compliance with the diet was subjectively assessed by the dietitian by weekly questioning of the parents and by scrutiny of the food diary records. Lapses from the diet were recorded by parents and defined as eating any food that was not allowed, as agreed with the investigators at the start of the diet. The level of compliance was defined as: (1) excellent (one or two dietary lapses over the whole six week period); (2) good (a maximum of one lapse per week); (3) average (a maximum of three lapses per week); and (4) poor (more than three lapses per week). Only records that were excellent, good, or average were used for the purposes of dietary analysis. The quality of food records was defined as (1) excellent (full details given for all food and drinks, all portions and plate waste measured); (2) good (good detail given and most foods weighed, very few estimated portions); (3) average (good detail given, at least $50 \%$ portions weighed); (4) poor (missing details, portion sizes guessed, less than $50 \%$ portions weighed); and (5) very poor (diet history only). Only those records considered to be average, good, or excellent were analysed.

Nutrient intake was analysed on a microcomputer with the microcomputer program 'Microdiet', ${ }^{7}$ using standard data on food composition ${ }^{8}$ and manufacturers' data, if required. Energy intake was calculated per $\mathrm{kg}$ body weight but all other nutrients were recorded in

Table 1 Characteristics of the few foods diets used by each group

\begin{tabular}{|c|c|c|}
\hline & $\begin{array}{l}\text { Whey hydrolysate } \\
\text { group }(n=21)\end{array}$ & $\begin{array}{l}\text { Casein hydrolysate } \\
\text { group }(n=24)\end{array}$ \\
\hline \multicolumn{3}{|c|}{ No of foods used in the few foods diets } \\
\hline Four & & 0 \\
\hline Five & 9 & 13 \\
\hline & 6 & 6 \\
\hline Seven & 2 & 3 \\
\hline Eight & 2 & 2 \\
\hline \multicolumn{3}{|c|}{ No of children receiving each food } \\
\hline Meat & & \\
\hline Lamb & 19 & 23 \\
\hline \multirow{2}{*}{\multicolumn{3}{|c|}{ Vegetable }} \\
\hline & & \\
\hline Rice & 20 & 22 \\
\hline Potato & 20 & 23 \\
\hline Cauliflower & 7 & 12 \\
\hline Cabbage & 3 & 5 \\
\hline Brussels sprouts & 4 & 3 \\
\hline $\begin{array}{l}\text { Broccoli } \\
\text { Green beans }\end{array}$ & 6 & 8 \\
\hline \multirow{2}{*}{\multicolumn{3}{|c|}{ Fruit }} \\
\hline & & \\
\hline Pear & 18 & 16 \\
\hline Apple & 4 & 4 \\
\hline Grape & 0 & 1 \\
\hline \multirow{2}{*}{\multicolumn{3}{|c|}{ Miscellaneous }} \\
\hline & & \\
\hline Sunflower oil & 4 & 3 \\
\hline Vegetable oil & 2. & 2 \\
\hline Olive oil & 1 & 0 \\
\hline Cucumber & 2 & 0 \\
\hline $\begin{array}{l}\text { Millet } \\
\text { S }\end{array}$ & 0 & 1 \\
\hline
\end{tabular}

\author{
Professor T J David, Booth \\ Professor T J David, Booth \\ Charlestown Road, Blackley \\ Manchester M9 7AA. \\ Accepted 2 May 1995 \\ University of \\ Health \\ D C Mabin \\ A E Sykes \\ T J David
}


Table 2 Compliance with diet and quality of food record of each group

\begin{tabular}{llll}
\hline & $\begin{array}{l}\text { Whey hydrolysate } \\
\text { group }(n=21)\end{array}$ & $\begin{array}{l}\text { Casein hydrolysate } \\
\text { group }(n=24)\end{array}$ & \\
\hline Compliance & & 7 & \\
$\quad$ Excellent & 7 & 7 & $\chi^{2}=0 \cdot 47, \mathrm{df}=2, \mathrm{p}=0 \cdot 69$ \\
$\quad$ Good & 6 & 10 & \\
$\begin{array}{l}\text { Average } \\
\text { Quality of food record }\end{array}$ & 8 & 7 & \\
$\quad$ Excellent & 8 & 7 & $\chi^{2}=0 \cdot 48, \mathrm{df}=2, \mathrm{p}=0 \cdot 79$ \\
$\quad$ Good & 6 & 10 & \\
Average & 7 & & \\
\hline
\end{tabular}

absolute values. All nutrients were expressed as a percentage of the dietary reference value ${ }^{9}$ appropriate for the age and sex of the child. Calcium, iron, zinc, folate (folic acid and free folate), and vitamin $C$ intakes were expressed as a percentage of the lower reference nutrient intake (LRNI). Energy and protein intakes were expressed as a percentage of the estimated average requirement (EAR), as the Department of Health dietary reference values do not specify an LRNI for either of these nutrients. ${ }^{9}$ The change in nutrient intake in individuals was calculated by subtracting the intake of the nutrient on the normal diet, expressed as a percentage of the appropriate dietary reference value, from the intake on the few foods diet.

The data were not normally distributed and therefore non-parametric methods were used throughout (Mann-Whitney test to compare the difference between groups and the Wilcoxon method to compare the change in nutrients within each group).

\section{Results}

Forty five children were studied. Twenty four (15 male, nine female; median age 1.8 years, range $0.6-8.9$ years) received a few foods diet supplemented with casein hydrolysate and 21 ( 11 male, 10 female; median age $2 \cdot 8$ years, range $0.6-11.5$ years) received a few foods diet supplemented with whey hydrolysate. The median age (difference between medians= 0.76 years, $95 \%$ confidence interval -0.15 , 1.9; Mann-Whitney, $\mathrm{p}=0 \cdot 1$ ) and sex distribution $(\chi=1, \mathrm{df}=1, \mathrm{p}=0.32)$ of the two groups were not significantly different. The range of foods allowed and number of children within each group taking these foods is given in table 1. The compliance and quality of food records was similar in both groups (table 2). There was a statistically significant reduction in protein and calcium intake in both groups and of energy in the casein hydrolysate group on the few foods diet (table 3 ). The median daily volume of hydrolysate milk taken was 10.5 $\mathrm{ml} /$ day (range $0-840 \mathrm{ml} /$ day) for the casein hydrolysate group and $267 \mathrm{ml} /$ day (range 0-1300 $\mathrm{ml} /$ day) for the whey hydrolysate group (table 3 ). The number of children in

Table 3 Median intake during normal and few foods diet and change in nutrient intake. Values given for the median (and range) intake during both periods are the actual intakes expressed as a percentage of the dietary reference values (EAR for energy and protein, LRNI for all the others). It should be noted that the median change (that is, the difference between medians) is calculated using the estimated medians and is not necessarily equal to the actual difference

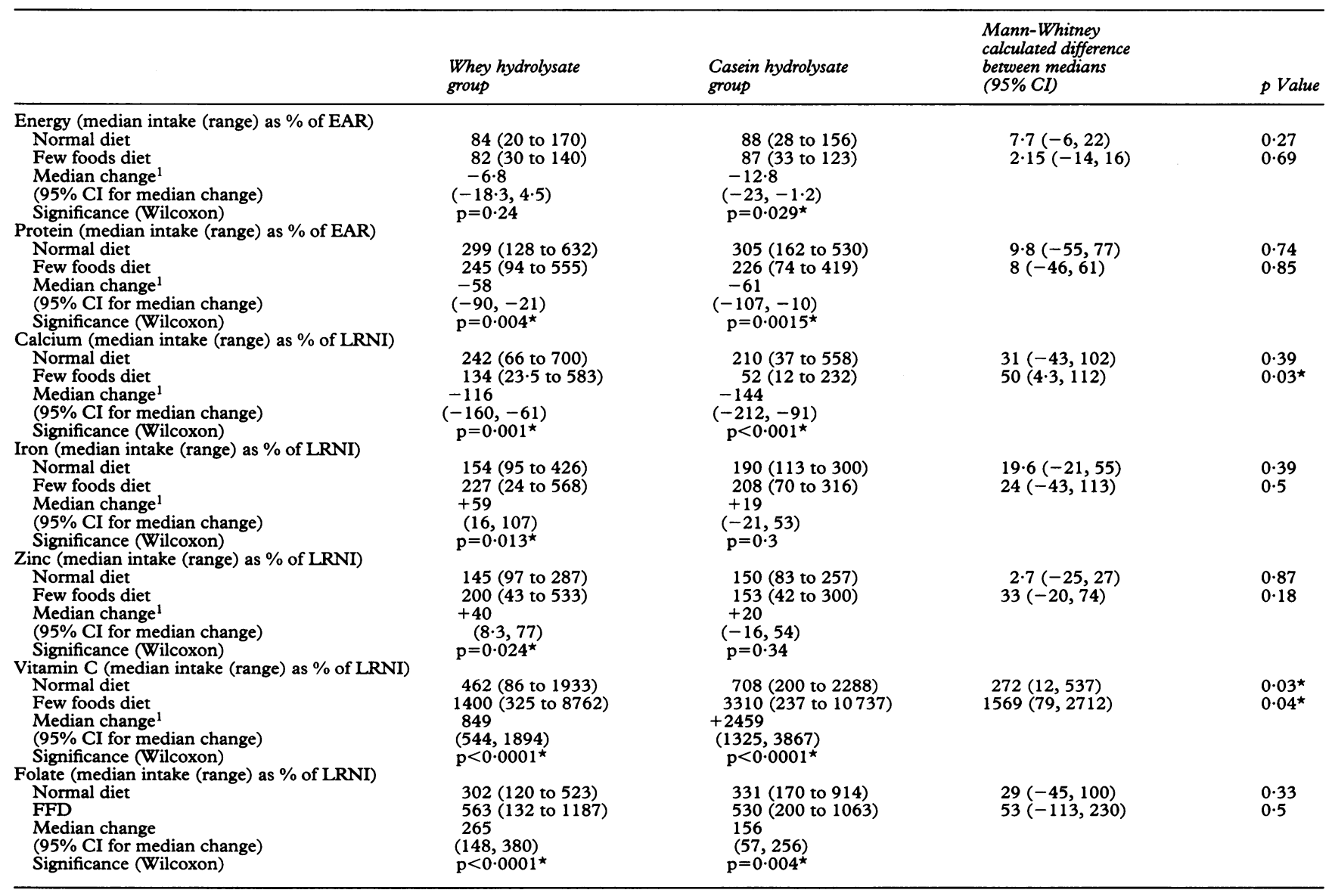

$E A R=$ estimated average requirement; $L R N I=$ lower reference nutrient intake; $C I=$ confidence interval.

${ }^{1}$ A negative number indicates a reduction in intake. ${ }^{\star}$ Denotes a statistically significant result. 
Table 4 Intake of nutrients relative to dietary reference values

\begin{tabular}{|c|c|c|c|c|}
\hline \multirow[b]{2}{*}{ Energy } & \multicolumn{2}{|c|}{$\begin{array}{l}\text { Whey hydrolysate } \\
\text { group }(n=21)\end{array}$} & \multicolumn{2}{|c|}{$\begin{array}{l}\text { Casein hydrolysate } \\
\text { group }(n=24)\end{array}$} \\
\hline & $>E A R$ & $<E A R$ & $>E A R$ & $<E A R$ \\
\hline $\begin{array}{l}\text { Energy } \\
\text { Normal diet } \\
\text { Few foods diet } \\
\text { Test }\end{array}$ & $\begin{array}{c}5 \\
3 \\
\chi^{2}=0.62\end{array}$ & $\begin{aligned} & 16 \\
& 18 \\
&= 0 \cdot 43\end{aligned}$ & $\begin{array}{l}8 \\
5 \\
\chi^{2}=0.95\end{array}$ & $\begin{array}{rl} & 16 \\
19 & 0 \cdot 33\end{array}$ \\
\hline $\begin{array}{l}\text { Protein } \\
\text { Normal diet } \\
\text { Few foods diet }\end{array}$ & 21 & $\begin{array}{l}0 \\
1\end{array}$ & 24 & $\begin{array}{l}0 \\
1\end{array}$ \\
\hline Calcium & $>L R N I$ & $<L R N I$ & $>L R N I$ & $<L R N I$ \\
\hline $\begin{array}{l}\text { Normal diet } \\
\text { Few foods diet } \\
\text { Test }\end{array}$ & $\begin{array}{l}20 \\
12 \\
\chi^{2}=8 \cdot 4,\end{array}$ & $\begin{array}{l}1 \\
\stackrel{9}{0.038^{\star}}\end{array}$ & $\begin{array}{l}21 \\
8 \\
\chi^{2}=14 \cdot 7\end{array}$ & $\begin{aligned} & 3 \\
16 & \\
= & 0.0001 \star\end{aligned}$ \\
\hline $\begin{array}{l}\text { Iron } \\
\text { Normal diet } \\
\text { Few foods diet } \\
\text { Test }\end{array}$ & $\begin{array}{l}x-0.79 \\
19\end{array}$ & $\begin{array}{l}2 \\
2\end{array}$ & $\begin{array}{l}24 \\
20 \\
\chi^{2}=4 \cdot 36\end{array}$ & $\begin{aligned} & 0 \\
& 4 \\
&= 0.04^{\star}\end{aligned}$ \\
\hline $\begin{array}{l}\text { Zinc } \\
\text { Normal diet } \\
\text { Few foods diet }\end{array}$ & $\begin{array}{l}20 \\
20\end{array}$ & $\begin{array}{l}1 \\
1\end{array}$ & $\begin{array}{l}22 \\
22\end{array}$ & $\begin{array}{l}2 \\
2\end{array}$ \\
\hline $\begin{array}{l}\text { Vitamin C } \\
\text { Normal diet } \\
\text { Few foods diet }\end{array}$ & $\begin{array}{l}20 \\
21\end{array}$ & $\begin{array}{l}1 \\
0\end{array}$ & $\begin{array}{l}24 \\
24\end{array}$ & $\begin{array}{l}0 \\
0\end{array}$ \\
\hline $\begin{array}{l}\text { Folate } \\
\text { Normal diet } \\
\text { Few foods diet }\end{array}$ & 21 & $\begin{array}{l}0 \\
0\end{array}$ & $\begin{array}{l}24 \\
24\end{array}$ & $\begin{array}{l}0 \\
0\end{array}$ \\
\hline
\end{tabular}

$\mathrm{EAR}=$ estimated average requirement: $\mathrm{LRNI}=$ lower reference nutrient intake.

$\star$ Denotes a statistically significant result.

each group whose intake of nutrient was less than or greater than the dietary reference value is given in table 4 . The median changes in individual nutrients are shown in the figure.

\section{Discussion}

The study does have some limitations. The diet was not identical in all children because it was tailored for individual children, but the total number of foods was limited to eight. Our assessment of adherence to and compliance with the diet was subjective and was not validated by the use of food markers. The six day weighed food record, if performed carefully, may be an accurate record of food intake, ${ }^{6}$ but

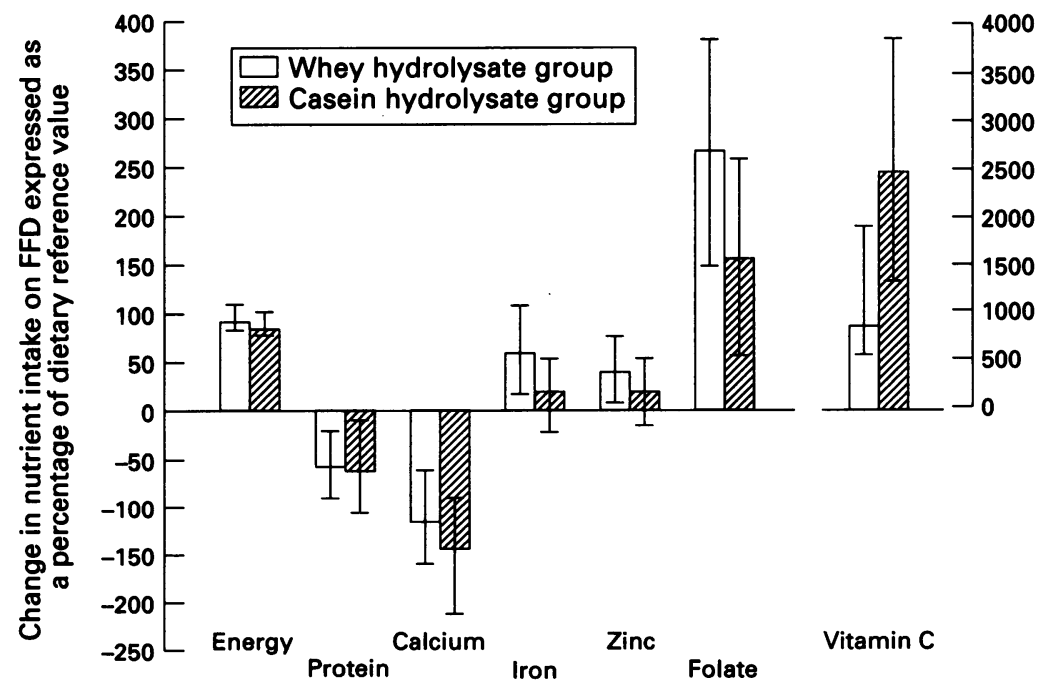

Median change (with $95 \%$ confidence limits) in individual nutrients, expressed as a percentage of the appropriate dietary reference value (estimated average requirement for energy and protein, lower reference nutrient intake for others). DRF=dietary reference value. in this study, its reproducibility and accuracy could not be measured as the study took place in an outpatient setting. In addition, it is acknowledged that the data and methods used to compile the dietary reference values may be inaccurate because of reporting error and wide day to day variation in intake. ${ }^{9}$ However, these values are widely used by dietitians to assess the nutritional adequacy of children's diets. There was also a high degree of withdrawal but this is a reflection of the strictness of the compliance and food record criteria that were set.

Despite these limitations, this study has documented that, even when supplemented with a protein hydrolysate formula, protein and calcium intake were significantly reduced during a few foods diet. The reduction in protein intake was unlikely to be clinically significant as the intake remained greater than the estimated average requirement in all but one patient. In contrast, calcium intake was greatly reduced. The median energy intake was significantly reduced in the casein hydrolysate group, but not in the whey hydrolysate group.

Calcium intakes below the lower reference nutrient intake did not occur in any children who took more than $200 \mathrm{ml} /$ day of the whey hydrolysate, which contains $88 \mathrm{mg}$ calcium per $100 \mathrm{ml}$, or in those who ingested more than $360 \mathrm{ml} /$ day of the casein hydrolysate, which contains $63 \mathrm{mg}$ calcium per $100 \mathrm{ml}$. Only one child over one year of age drank more than 360 $\mathrm{ml} /$ day of the casein hydrolysate compared to 11 children over one year of age who drank more than $200 \mathrm{ml} /$ day of the whey hydrolysate, and it would appear that palatability is important in determining intake of these formulas. The use of the whey hydrolysate, however, did not eliminate the risk of calcium deficiency.

We thank Sally Hollis of the Computation and Statistics Unit Hope Hospital, Salford, John Stanton, Chief Dietitian, and Aileen McCann, Senior Paediatric Dietitian, for their help and advice. DCM and AES were supported by a grant from Nutricia Cow and Gate.

1 Mabin DC, Sykes AE, David TJ. Controlled trial of a few foods diet in severe atopic dermatitis. Arch Dis Child 1995; 73: 202-7

2 David TJ. Dietary treatment of atopic eczema. Arch Dis Child 1989; 64: 1506-9.

3 Devlin J, David TJ, Stanton RHJ. Six food diet for childhood atopic eczema. Acta Derm Venereol (Stockh) 1991; 71: $20-4$.

4 Juto $P$, Engberg $S$, Winberg J. Treatment of infantile atopic dermatitis with a strict elimination diet. Clin Allergy 1978; 8: 493-500.

5 Pike MG, Carter CM, Boulton P, Turner MW, Soothill JF Atherton DJ. Few foods diet in the treatment of atopic Atherton DJ. Few foods diet in the treatm

6 Bingham SA. The dietary assessment of individuals, methods, accuracy, new techniques and recommendations. methods, accuracy, new techniques and recon

7 Microdiet SUMS ver 8.4. Salford: Department of Mathematics and Computer Science, University of

8 Holland B, Welch AA, Unwin ID, Buss DH, Paul AA Southgate DAT, eds. McCance and Widdowson's the composition of foods. 5th Ed. London: Royal Society of Chemistry/MAFF, 1991

9 Department of Health. Report on health and social subjects No 41 . Dietary reference values for food energy and nutrient for the United Kingdom. Report of the panel on dietary reference values of the Committee on Medical Aspects of Food Policy. London: HMSO, 1991. 